\title{
Spotlight on the Binding Affinity of Ion Channels for Phosphoinositides: From the Study of Sperm Flagellum
}

\author{
Takafumi Kawai ${ }^{1 *}$ and Yasushi Okamura ${ }^{1,2}$ \\ 1 Integrative Physiology Program, Graduate School of Medicine, Osaka University, Suita, Japan, ${ }^{2}$ Graduate School \\ of Frontier Bioscience, Osaka University, Suita, Japan
}

The previous studies revealed that many types of ion channels have sensitivity to Ptdlns $(4,5) \mathrm{P}_{2}$, which has been mainly shown using heterologous expression system. On the other hand, there remains few evidence showing that $\operatorname{Ptdlns}(4,5) \mathrm{P}_{2}$ natively regulate the ion channel activities in physiological context. Our group recently discovered that a sperm specific $\mathrm{K}^{+}$channel, Slo3, is natively regulated by Ptdlns $(4,5) \mathrm{P}_{2}$ in sperm flagellum. Very interestingly, a principal piece, to which Slo3 specifically localized, had extremely low density of Ptdlns $(4,5) \mathrm{P}_{2}$ compared to the regular cell plasma membrane. Furthermore, our studies and the previous ones also revealed that Slo3 had much stronger Ptdlns $(4,5) \mathrm{P}_{2}$ affinity than KCNQ2/3 channels, which are widely regulated by endogenous Ptdlns $(4,5) \mathrm{P}_{2}$ in neurons. Thus, the high-Ptdlns $(4,5) \mathrm{P}_{2}$ affinity of Slo3 is well-adapted to the specialized Ptdlns $(4,5) \mathrm{P}_{2}$ environment in the principal piece. This study sheds light on the relationship between Ptdlns $(4,5) \mathrm{P}_{2}$-affinity of ion

OPEN ACCESS

Edited by: Andrea Saponaro, University of Milan, Italy

Reviewed by: Fan Yang,

Zhejiang University, China

*Correspondence: Takafumi Kawai kawai@phys2.med.osaka-u.ac.jp

Specialty section: This article was submitted to Membrane Physiology and Membrane Biophysics, a section of the journal Frontiers in Physiology

Received: 13 December 2021 Accepted: 07 January 2022 Published: 07 February 2022

Citation:

Kawai T and Okamura Y (2022) Spotlight on the Binding Affinity of Ion Channels for Phosphoinositides: From

the Study of Sperm Flagellum.

Front. Physiol. 13:834180.

doi: $10.3389 /$ fphys.2022.834180 channels and their Ptdlns $(4,5) \mathrm{P}_{2}$ environment in native cells. We discuss the current understanding about Ptdlns(4,5) $\mathrm{P}_{2}$ affinity of diverse ion channels and their possible regulatory mechanism in native cellular environment.

Keywords: phosphoinositides, ion channel, voltage-sensing phosphatase, sperm flagellum, Slo3, KCNQ

\section{INTRODUCTION}

Phosphoinositides (PIPs) comprise a minor proportion of the lipid membrane, but they play important roles in a variety of physiological processes, including signal transduction, regulation of cytoskeleton, exocytosis, and endocytosis (Balla, 2013). Specifically, PtdIns(4,5) $\mathrm{P}_{2}$, one class of PIPs, mainly exists in the inner leaflet of the plasma membrane. Accumulating evidence suggest that PtdIns $(4,5) \mathrm{P}_{2}$ also regulates the property of diverse ion channels in many aspects (Suh and Hille, 2005, 2008; Okamura et al., 2018). For example, PtdIns(4,5) $\mathrm{P}_{2}$ is required for the basal activities of all five members of voltage-gated potassium KCNQ/Kv7 channels (Kv7.1-7.5 or KCNQ1-5) (Zhang et al., 2003). Currently, more than 50 ion channel molecules are identified as the targets of PtdIns $(4,5) \mathrm{P}_{2}$ regulation from the electrophysiological studies using heterologous expression system (Suh and Hille, 2008; Okamura et al., 2018). In these studies, the PtdIdns(4,5) $\mathrm{P}_{2}$ dependency of ion channels are examined using application of soluble short chain PtdIdns $(4,5) \mathrm{P}_{2}$, activation of voltage-sensing phosphatase (VSP), or Gq-couple receptors activation. In contrast to the plenty of knowledge about ion channel regulation by $\operatorname{PtdIns}(4,5) \mathrm{P}_{2}$ from these experiments, the number of reports about these regulatory mechanisms is quite limited in native physiological condition. The evidence of its physiological importance originates in the study of M-current in sympathetic neurons (Brown and Adams, 1980), which is now widely observed in various types of neurons. The M-current is evoked by the stimulation of muscarinic acetylcholine receptors 
(mAchRs), which activates GPCR/Gq signaling cascade and reduces the $\operatorname{PtdIns}(4,5) \mathrm{P}_{2}$ level in plasma membrane. The reduced PtdIns $(4,5) \mathrm{P}_{2}$ level causes the suppression of KCNQ2/3 channel activities, inducing the depolarization of neurons. The observation of $\mathrm{M}$-current in native neurons indicates that KCNQ channels is constitutively activated by $\operatorname{PtdIns}(4,5) \mathrm{P}_{2}$ in normal condition, and the change of $\operatorname{PtdIns}(4,5) \mathrm{P}_{2}$ level is also physiologically important for the neural function. Our group recently reported that Slo3, a sperm specific $\mathrm{K}^{+}$channel, is natively regulated by $\operatorname{PtdIns}(4,5) \mathrm{P}_{2}$ in sperm flagellum (Kawai et al., 2019). We analyzed the function of VSP, which dephosphorylates Ptdins(4,5) $\mathrm{P}_{2}$ into PtdIns(4)P, in a mouse spermatozoa. We found that the amount of $\operatorname{PtdIns}(4,5) \mathrm{P}_{2}$ was significantly and highly upregulated in a VSP-deficient spermatozoa, thereby the activity of Slo3 was significantly increased (Figure 1A; Kawai et al., 2019), which is consistent with the previous report that $\mathrm{Slo} 3$ is sensitive to $\operatorname{PtdIns}(4,5) \mathrm{P}_{2}$ (Tang et al., 2010). Importantly, we observed that the principal piece, to which Slo3 specifically localizes, showed extremely low density of PtdIns $(4,5) \mathrm{P}_{2}$ compared with the previously reported regular plasma membrane (Kawai et al., 2019). The Slo3 has strong binding affinity for $\operatorname{PtdIns}(4,5) \mathrm{P}_{2}$ and the low level of PtdIns $(4,5) \mathrm{P}_{2}$ appears to adjust to the high-affinity of Slo3 for proper regulation (Figure 1B). The previous reports indicate that Slo3 has more than 10-fold higher affinity for $\operatorname{PtdIns}(4,5) \mathrm{P}_{2}$ than KCNQ2/3 channels and that the PtdIns $(4,5) \mathrm{P}_{2}$ level in principal piece is also less than one-tenth of the regular plasma membrane as reported in fibroblast (Fujita et al., 2009). Thus, the study sheds light on the importance of focusing on the relationship between $\operatorname{PtdIns}(4,5) \mathrm{P}_{2}$-affinity of ion channels and the native PtdIns $(4,5) \mathrm{P}_{2}$ level. Nevertheless, we sometimes discuss the PtdIns $(4,5) \mathrm{P}_{2}$-sensitivity of ion channels in an allor-none manner, and the affinity of $\operatorname{PtdIns}(4,5) \mathrm{P}_{2}$ is not so importantly discussed. In the present mini-review, we describe how the PtdIns $(4,5) \mathrm{P}_{2}$ sensitivity or affinity of ion channels has been examined in heterologous expression system at first. Then, we introduce the list of $\operatorname{PtdIns}(4,5) \mathrm{P}_{2}$-sensitive ion channels with their affinity as described. Finally, we discuss the possibility that different PtdIns $(4,5) \mathrm{P}_{2}$-affinity of ion channels are regulated in different $\operatorname{PtdIns}(4,5) \mathrm{P}_{2}$ environment of specialized subcellular compartments.

\section{Quantifying the Affinity of Ion Channels for Ptdlns $(4,5) \mathrm{P}_{2}$ Using Heterologous Expression System}

The PtdIns $(4,5) \mathrm{P}_{2}$-sensitivity of ion channels is also mostly examined by electrophysiology. The ion channel of interest is heterologously expressed in Xenopus oocyte or other cell lines such as Human Embryonic Kidney cells 293 (HEK-293) or Chinese hamster ovary $(\mathrm{CHO})$ cells. There are several techniques to manipulate plasma membrane $\operatorname{PtdIns}(4,5) \mathrm{P}_{2}$ levels so that the change in ion channel activities is monitored. For example, heterologous expression of Gq-couple receptors such as muscarinic acetylcholine receptor M1 is widely used for this purpose. The agonist stimulation cleaves $\operatorname{PtdIns}(4,5) \mathrm{P}_{2}$ to reduce its level on the plasma membrane. Furthermore,

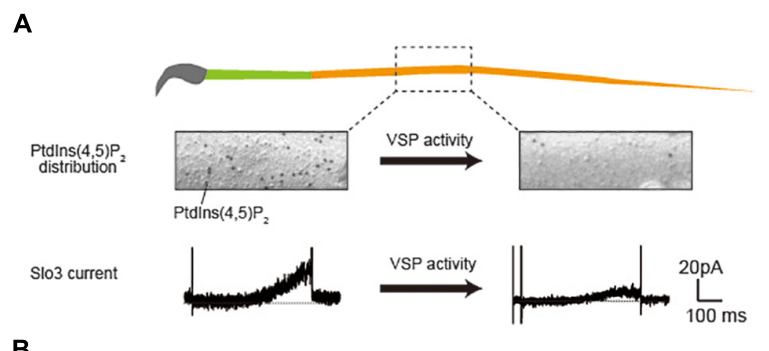

B

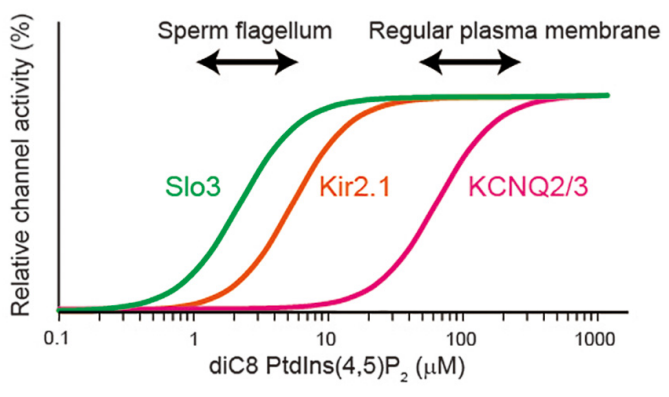

FIGURE 1 | Possible relationship between Ptdlns(4,5) $\mathrm{P}_{2}$ concentration and its affinity for ion channels. (A) Voltage-sensing phosphatase (VSP) reduces the Ptdlns $(4,5) \mathrm{P}_{2}$ levels in sperm flagellum, regulating Slo3 activity. The figure is illustrated based on the finding in our previous report (Kawai et al., 2019). The Ptdlns $(4,5) \mathrm{P}_{2}$ is detected by freeze-fracture electron microscopy. The VSP changes the distribution of Ptdlns $(4,5) \mathrm{P}_{2}$ levels and regulates Slo3 activity. The Slo3 activity was measured by perforated patch clamp recording (Kawai et al., 2019). (B) Diagram showing the different Ptdlns $(4,5) P_{2}$ dependency among different ion channels.

a rapamycin-inducible phosphatase, Pseudojanin, strongly depletes PtdIns(4,5) $\mathrm{P}_{2}$, as well as PtdIns(4)P (Hammond et al., 2012). Although these chemical techniques are important molecular tools to manipulate the $\operatorname{PtdIns}(4,5) \mathrm{P}_{2}$, it may not be suited for estimating PtdIns $(4,5) \mathrm{P}_{2}$-affinity of ion channel due to the difficulty in precisely manipulating the $\operatorname{Ptd} \operatorname{Ins}(4,5) \mathrm{P}_{2}$ levels.

The most quantitative method to analyze $\operatorname{PtdIns}(4,5) \mathrm{P}_{2}-$ affinity is performed by directly applying a soluble short acyl chain PtdIns $(4,5) \mathrm{P}_{2}$ to the inner leaflet of plasma membrane in an inside-out configuration. This method allows to describe a dose-response curve and to calculate the Kd-value, suited for discussing the PtdIns $(4,5) \mathrm{P}_{2}$-affinity of ion channels. On the other hand, because this technique uses short acyl chain PtdIns(4,5) $\mathrm{P}_{2}$ instead of native long acyl chain lipids, it may show some artificial effects on ion channel properties. Indeed, although the PtdIns $(4,5) \mathrm{P}_{2}$ sensitivity of several $\mathrm{K}^{+}$channels has been already reported by perfusing soluble $\operatorname{PtdIns}(4,5) \mathrm{P}_{2}$, the sensitivity has not been reproduced using other techniques to deplete PtdIns(4,5) $\mathrm{P}_{2}$ (Kruse et al., 2012). A possible alternative way to estimate PtdIns $(4,5) \mathrm{P}_{2}$-affinity is using VSP, which dephosphorylates $\operatorname{Ptd} \operatorname{Ins}(4,5) \mathrm{P}_{2}$ in response to the depolarization (Murata et al., 2005). Because VSP depletes the endogenous PtdIns $(4,5) \mathrm{P}_{2}$ by its enzyme activity, it can examine the importance of the regulation by $\operatorname{PtdIns}(4,5) \mathrm{P}_{2}$ in a more physiological aspect. Although the quantitativity of VSP for PtdIns $(4,5) \mathrm{P}_{2}$-affinity is not more precise than that of soluble 
TABLE 1 | The Ptdlns(4,5) $\mathrm{P}_{2}$ affinity of individual ion channels.

\begin{tabular}{|c|c|c|}
\hline $\begin{array}{l}\text { Name of the ion } \\
\text { channel }\end{array}$ & $\mathbf{K d}(\mu \mathrm{M})$ & References \\
\hline Kv7.2/Kv7.3 & $\sim 87$ & Zhang et al., 2003; Li et al., 2005 \\
\hline Kir2.1 & $\sim 5$ & Lopes et al., 2002; Du et al., 2004 \\
\hline Kir2.3 & $\sim 29$ & Du et al., 2004; Ha et al., 2018 \\
\hline Kir3.4 & $17.7 \pm 1.0$ & Jin et al., 2002 \\
\hline TREK-1 & 0.125 & Chemin et al., 2005 \\
\hline Slo3 & $2.4 \pm 0.3$ & Tang et al., 2010 \\
\hline $\mathrm{BK}$ & $\begin{array}{c}\sim 14\left(0\left[\mathrm{Ca}^{2+}\right]_{\mathrm{i}}\right) \sim 6(100 \\
\left.\mu \mathrm{M}\left[\mathrm{Ca}^{2+}\right]_{\mathrm{i}}\right)\end{array}$ & Tang et al., 2014 \\
\hline SK2 & $1.9 \pm 0.22$ & Zhang et al., 2015 \\
\hline TRPV1 & $0.60 \pm 0.2$ & Ufret-Vincenty et al., 2011 \\
\hline TRPV6 & $78.9 \pm 6.5$ & Velisetty et al., 2016 \\
\hline TRPM2 & $11.9 \pm 1.1$ & Barth et al., 2021 \\
\hline TRPM8 & $\begin{array}{c}80.7\left(25^{\circ} \mathrm{C}\right) 38.2\left(17^{\circ} \mathrm{C}\right) \\
4.69\left(17^{\circ} \mathrm{C} \text { with } 500 \mu \mathrm{M}\right. \\
\text { menthol })\end{array}$ & Rohacs et al., 2005 \\
\hline TMEM16A & $1.95\left(0.5 \mu \mathrm{M}\left[\mathrm{Ca}^{2+}\right]_{\mathrm{i}}\right)$ & Le et al., 2019 \\
\hline TMEM16F & $5.8 \pm 0.5$ & Ye et al., 2018 \\
\hline $\mathrm{P} 2 \times 7$ & $20-30$ & Zhao et al., 2007 \\
\hline $\mathrm{HCN}$ & 10.9 & Pian et al., 2006 \\
\hline
\end{tabular}

PtdIns $(4,5) \mathrm{P}_{2}$ perfusion, the strength of VSP activity can be easily controlled by changing the amplitude, duration, and/or number of the depolarization pulses, conferring a certain level of quantitativity to it. Ideally, it should be the best way to quantify the PtdIns $(4,5) \mathrm{P}_{2}$-affinity of ion channels by soluble PtdIns $(4,5) \mathrm{P}_{2}$ perfusion and confirm the result using VSP experiments.

\section{Difference in the Ptdlns $(4,5) \mathrm{P}_{2}$-Affinity Among lon Channels}

As described above, more than 50 ion channel molecules have already been shown to be PtdIns $(4,5) \mathrm{P}_{2}$-sensitive (Suh and Hille, 2005, 2008; Okamura et al., 2018), including $\mathrm{K}^{+}$channels, $\mathrm{Ca}^{2+}$ channels, TRP channels, $\mathrm{P} 2 \mathrm{X}$ receptors, NMDA receptors, and so on. Some studies also performed the detailed experiments and estimated the Kd value of $\operatorname{PtdIns}(4,5) \mathrm{P}_{2}$-affinity by perfusing a short acyl chain $\operatorname{PtdIns}(4,5) \mathrm{P}_{2}$. We listed the representative examples of the PtdIns(4,5) $\mathrm{P}_{2}$ affinity of ion channels (Table 1). As shown in Table 1, the Kd value for $\operatorname{PtdIns}(4,5) \mathrm{P}_{2}$ sensitivity of ion channels has large variation, ranging from $100 \mathrm{nM}$ to $100 \mu \mathrm{M}$. The PtdIns $(4,5) \mathrm{P}_{2}$-affinities of ion channels themselves may also change depending on the states of channel activity. For example, TRPM8, which is activated by both cold and menthol, changes their apparent PtdIns $(4,5) \mathrm{P}_{2}$ affinity in response to the agonistic stimuli; cold and menthol (Rohacs et al., 2005). Similarly, BK, $\mathrm{Ca}^{2+}$ activated- $\mathrm{K}^{+}$channels (Tang et al., 2014), and TMEM16A, $\mathrm{Ca}^{2+}$ activated- $\mathrm{Cl}^{-}$channels, also show different affinity to PtdIns $(4,5) \mathrm{P}_{2}$ depending on the intracellular $\mathrm{Ca}^{2+}$ concentration (Le et al., 2019).

In most cases, PtdIns $(4,5) \mathrm{P}_{2}$ electrostatically interacts with positive charge residues, such as lysine and arginine, through its negative charge on the hydrophilic head group. However, the regulatory mechanism of ion channel activity by $\operatorname{PtdIns}(4,5) \mathrm{P}_{2}$ is sometimes complicated and involves multiple sites of the ion channels. In KCNQ2/3, which is one of the most investigated ion channels about PtdIns $(4,5) \mathrm{P}_{2}$ regulation, the studies suggest that there are multiple interacting sites with $\operatorname{PtdIns}(4,5) \mathrm{P}_{2}$; the interface of voltage sensor domain and pore-gate domain, the helix A-B linker site, and the distal C-terminus site (Zaydman and Cui, 2014). Recent cryo-EM structures of KCNQ channels with PtdIns $(4,5) \mathrm{P}_{2}$ also support the idea that PtdIns $(4,5) \mathrm{P}_{2}$ interacts with voltage sensor and pore-gate domains (Sun and Mackinnon, 2017, 2020; Zheng et al., 2021). On the other hand, in Kir2.2, it is proposed that PtdIns $(4,5) \mathrm{P}_{2}$ binds at an interface between the transmembrane and the cytoplasmic domains, opening the inner helix gate (Hansen et al., 2011). The full-length protein structure of $\mathrm{Slo} 3$ has not been resolved so far, but the previous mutation analysis indicates that $\operatorname{PtdIns}(4,5) \mathrm{P}_{2}$ binds to positive charge residues located at the linker region between pore-gate domain and cytosolic RCK1 domain (Tang et al., 2010). Thus, the regulatory mechanism by $\operatorname{PtdIns}(4,5) \mathrm{P}_{2}$ of ion channels are diverse and sometimes so complicated, making it difficult to predict which residue is responsible for $\operatorname{PtdIns}(4,5) \mathrm{P}_{2}$ sensitivity only from the 3D structure information. Such diverse regulatory mechanism of by PtdIns $(4,5) \mathrm{P}_{2}$ may partially explain the reason why the PtdIns $(4,5) \mathrm{P}_{2}$ affinities are totally different among different types of ion channels.

\section{Relationship Between Ptdlns $(4,5) \mathrm{P}_{2}$ -Affinity of Ion Channels and the Ptdlns $(4,5) \mathbf{P}_{2}$ Environment}

How is such PtdIns $(4,5) \mathrm{P}_{2}$ affinity important for the regulation of native ion channel activities? In spite of many reports about PtdIns $(4,5) \mathrm{P}_{2}$ sensitivity in ion channels described above, there are only a few examples showing that the native ion channel activities are regulated by change of $\operatorname{PtdIns}(4,5) \mathrm{P}_{2}$ level in physiological condition. The most representative example is the regulation of KCNQ2/3 activity by $\mathrm{mAchR}$ activation, which is known as M-current. Because KCNQ2/3 is constitutively activated by endogenous $\operatorname{PtdIns}(4,5) \mathrm{P}_{2}$, the reduction of PtdIns $(4,5) \mathrm{P}_{2}$ closes the KCNQ2/3, inducing the depolarization of the cell. Another example was recently reported from our group (Kawai et al., 2019). We found that a sperm specific $\mathrm{K}^{+}$channel, Slo3, which is also PtdIns(4,5) $\mathrm{P}_{2}$-sensitive (Tang et al., 2010), is regulated by VSP activity.

To understand the mechanism of ion channel regulation by native PtdIns $(4,5) \mathrm{P}_{2}$, it is important to consider the relationship between PtdIns(4,5) $\mathrm{P}_{2}$-affinity and membrane $\operatorname{PtdIns}(4,5) \mathrm{P}_{2}$ concentration (Figure 1B). The affinity of KCNQ2/3 for $\operatorname{PtdIns}(4,5) \mathrm{P}_{2}$ is reported to be rather low among $\operatorname{PtdIns}(4,5) \mathrm{P}_{2}$ sensitive ion channels (Table 1). Importantly, the $\mathrm{Kd}$ value of KCNQ2/3 $(\sim 87 \mu \mathrm{M})$ is supposed to be similar to the plasma membrane's PtdIns $(4,5) \mathrm{P}_{2}$ level in regular cells (Figure 1B). On the other hand, the affinity of Slo3 for $\operatorname{PtdIns}(4,5) \mathrm{P}_{2}$ $(\mathrm{Kd}=\sim 2.5 \mu \mathrm{M})$ is more than 10-fold higher than that of KCNQ2/3 (Figure 1B). Interestingly, VSP generates biased distribution of PtdIns $(4,5) \mathrm{P}_{2}$ in sperm flagellum, optimizing 
the flagellar PtdIns $(4,5) \mathrm{P}_{2}$ environment for regulating a highaffinity Slo3 channel activity. Collectively, PtdIns(4,5) $\mathrm{P}_{2}$-affinity of ion channels must be in the range of physiological change for dynamic regulation of activity.

As shown in Table 1, a large proportion of ion channels have much stronger affinity for $\operatorname{PtdIns}(4,5) \mathrm{P}_{2}$ than KCNQ2/3. This fact appears to indicate that only a minor population of PtdIns $(4,5) \mathrm{P}_{2}$-sensitive ion channels would be natively regulated by the change of PtdIns $(4,5) \mathrm{P}_{2}$ level in plasma membrane of regular cells. However, it is noteworthy that the distribution of PtdIns $(4,5) \mathrm{P}_{2}$ in plasma membrane is sometimes heterogeneous. The previous reports showed that $\operatorname{PtdIns}(4,5) \mathrm{P}_{2}$ is concentrated at the rim of caveolae, a subset type of lipid raft, in cultured fibroblasts and smooth muscle cells of a mouse using freezefracture replica method (Fujita et al., 2009). Furthermore, it has been recently shown that there is compartmentalization of PtdIns(4,5) $\mathrm{P}_{2}$ metabolism; PtdIns $(4,5) \mathrm{P}_{2}$ break-down by $\mathrm{G}$ protein/PLC pathway is more rapid in cholesterol-rich domain (raft domain) than in cholesterol-poor domains (non-raft domain) of the plasma membrane (Myeong et al., 2021). These lines of evidence may suggest that lipid raft structure is more suited for regulating ion channel activities for $\operatorname{PtdIns}(4,5) \mathrm{P}_{2}$ low-affinity ion channels due to the abundant PtdIns $(4,5) \mathrm{P}_{2}$ level.

The level of PtdIns $(4,5) \mathrm{P}_{2}$ can also be a variable depending on the subcellular compartments. For example, $\operatorname{PtdIns}(4,5) \mathrm{P}_{2}$ is enriched in dendritic spines of cultured hippocampal neurons (Horne and Dell'acqua, 2007). The specialized structures such as flagellum or cilia can also have different $\operatorname{PtdIns}(4,5) \mathrm{P}_{2}$ environment. As described above, we discovered that sperm flagellum show extremely low level of $\operatorname{PtdIns}(4,5) \mathrm{P}_{2}$ due to VSP activity. Furthermore, several reports revealed that primary cilia,

\section{REFERENCES}

Balla, T. (2013). Phosphoinositides: tiny lipids with giant impact on cell regulation. Physiol. Rev. 93, 1019-1137. doi: 10.1152/physrev.00028.2012

Barth, D., Luckhoff, A., and Kuhn, F. J. P. (2021). Species-Specific Regulation of TRPM2 by PI(4,5)P2 via the Membrane Interfacial Cavity. Int. J. Mol. Sci. 22:4637. doi: 10.3390/ijms22094637

Brown, D. A., and Adams, P. R. (1980). Muscarinic suppression of a novel voltagesensitive K+ current in a vertebrate neurone. Nature 283, 673-676. doi: 10.1038/ 283673a0

Chavez, M., Ena, S., Van Sande, J., De Kerchove D’exaerde, A., Schurmans, S., and Schiffmann, S. N. (2015). Modulation of Ciliary Phosphoinositide Content Regulates Trafficking and Sonic Hedgehog Signaling Output. Dev. Cell 34, 338-350. doi: 10.1016/j.devcel.2015.06.016

Chemin, J., Patel, A. J., Duprat, F., Lauritzen, I., Lazdunski, M., and Honore, E. (2005). A phospholipid sensor controls mechanogating of the K+ channel TREK-1. EMBO J. 24, 44-53. doi: 10.1038/sj.emboj.7600494

Du, X., Zhang, H., Lopes, C., Mirshahi, T., Rohacs, T., and Logothetis, D. E. (2004). Characteristic interactions with phosphatidylinositol 4,5-bisphosphate determine regulation of kir channels by diverse modulators. J. Biol. Chem. 279, 37271-37281. doi: 10.1074/jbc.M403413200

Fujita, A., Cheng, J., Tauchi-Sato, K., Takenawa, T., and Fujimoto, T. (2009). A distinct pool of phosphatidylinositol 4,5-bisphosphate in caveolae revealed by a nanoscale labeling technique. Proc. Natl. Acad. Sci. U.S.A. 106, 9256-9261. doi: 10.1073/pnas.0900216106

Garcia-Gonzalo, F. R., Phua, S. C., Roberson, E. C., Garcia, G. III, Abedin, M., Schurmans, S., et al. (2015). Phosphoinositides Regulate Ciliary Protein a non-motile single sensory organelle, show extremely low level of PtdIns $(4,5) \mathrm{P}_{2}$ due to accumulation of Inpp5e, a phosphoinositide 5-phosphatase (Chavez et al., 2015; Garcia-Gonzalo et al., 2015). Interestingly, this PtdIns $(4,5) \mathrm{P}_{2}$ level can also be dynamically regulated by the depletion of Inpp5e during cell-division cycle (Phua et al., 2017). Therefore, the activity of high $\operatorname{PtdIns}(4,5) \mathrm{P}_{2}$ affinity ion channels, if there is any in primary cilia, could be regulated during the cell division cycles.

Overall, the different PtdIns $(4,5) \mathrm{P}_{2}$-affinity among ion channels may implicate that their regulation by $\operatorname{PtdIns}(4,5) \mathrm{P}_{2}$ is dependent on the individual $\operatorname{PtdIns}(4,5) \mathrm{P}_{2}$ environment, although it is also possible that $\operatorname{PtdIns}(4,5) \mathrm{P}_{2}$-affinity have the other significance than regulation of ion channel activity, such as localization and trafficking of ion channels (Van Den Bogaart et al., 2011). In any case, it is important to focus on the PtdIns $(4,5) \mathrm{P}_{2}$-affinity, as well as the spatial information, to precisely examine the ion channel function in the future.

\section{AUTHOR CONTRIBUTIONS}

TK and YO wrote the draft of the manuscript and approved the submitted version.

\section{FUNDING}

This work was supported by Grants-in-Aid from the Japan Society for the Promotion of Science (JSPS) (19H03401 to YO and 20K07274 to TK), the Ministry of Education, Culture, Sports, Science, and Technology (MEXT) (15H05901 to YO).

Trafficking to Modulate Hedgehog Signaling. Dev. Cell 34, 400-409. doi: 10. 1016/j.devcel.2015.08.001

Ha, J., Xu, Y., Kawano, T., Hendon, T., Baki, L., Garai, S., et al. (2018). Hydrogen sulfide inhibits Kir2 and Kir3 channels by decreasing sensitivity to the phospholipid phosphatidylinositol 4,5-bisphosphate (PIP2). J. Biol. Chem. 293, 3546-3561. doi: 10.1074/jbc.RA117.001679

Hammond, G. R., Fischer, M. J., Anderson, K. E., Holdich, J., Koteci, A., Balla, T., et al. (2012). PI4P and $\mathrm{PI}(4,5) \mathrm{P}_{2}$ are essential but independent lipid determinants of membrane identity. Science 337, 727-730. doi: 10.1126/science. 1222483

Hansen, S. B., Tao, X., and Mackinnon, R. (2011). Structural basis of $\mathrm{PIP}_{2}$ activation of the classical inward rectifier $\mathrm{K}^{+}$channel $\mathrm{K}_{i r} 2.2$. Nature $477,495-498$.

Horne, E. A., and Dell'acqua, M. L. (2007). Phospholipase C is required for changes in postsynaptic structure and function associated with NMDA receptordependent long-term depression. J. Neurosci. 27, 3523-3534. doi: 10.1523/ JNEUROSCI.4340-06.2007

Jin, T., Peng, L., Mirshahi, T., Rohacs, T., Chan, K. W., Sanchez, R., et al. (2002). The (beta)gamma subunits of $\mathrm{G}$ proteins gate a $\mathrm{K}(+)$ channel by pivoted bending of a transmembrane segment. Mol. Cell. 10, 469-481. doi: 10.1016/ s1097-2765(02)00659-7

Kawai, T., Miyata, H., Nakanishi, H., Sakata, S., Morioka, S., Sasaki, J., et al. (2019). Polarized PtdIns(4,5)P2 distribution mediated by a voltage-sensing phosphatase (VSP) regulates sperm motility. Proc. Natl. Acad. Sci. U.S.A. 116, 26020-26028. doi: 10.1073/pnas.191686 7116

Kruse, M., Hammond, G. R. V., and Hille, B. (2012). Regulation of voltage-gated potassium channels by $\mathrm{PI}(4,5) \mathrm{P}_{2}$. J. Gen. Physiol. 140, 189-205. 
Le, S. C., Jia, Z., Chen, J., and Yang, H. (2019). Molecular basis of PIP2-dependent regulation of the $\mathrm{Ca}(2+)$-activated chloride channel TMEM16A. Nat. Commun. 10:3769.

Li, Y., Gamper, N., Hilgemann, D. W., and Shapiro, M. S. (2005). Regulation of $\mathrm{K}_{v} 7$ (KCNQ) $\mathrm{K}^{+}$channel open probability by phosphatidylinositol 4,5bisphosphate. J. Neurosci. 25, 9825-9835. doi: 10.1523/JNEUROSCI.2597-05. 2005

Lopes, C. M., Zhang, H., Rohacs, T., Jin, T., Yang, J., and Logothetis, D. E. (2002). Alterations in conserved $\mathrm{K}_{i r}$ channel-PIP 2 interactions underlie channelopathies. Neuron 34, 933-944. doi: 10.1016/s0896-6273(02)00725-0

Murata, Y., Iwasaki, H., Sasaki, M., Inaba, K., and Okamura, Y. (2005). Phosphoinositide phosphatase activity coupled to an intrinsic voltage sensor. Nature 435, 1239-1243. doi: 10.1038/nature03650

Myeong, J., Park, C. G., Suh, B. C., and Hille, B. (2021). Compartmentalization of phosphatidylinositol 4,5-bisphosphate metabolism into plasma membrane liquid-ordered/raft domains. Proc. Natl. Acad. Sci. U.S.A. 118:e2025343118. doi: $10.1073 /$ pnas. 2025343118

Okamura, Y., Kawanabe, A., and Kawai, T. (2018). Voltage-Sensing Phosphatases: Biophysics, Physiology, and Molecular Engineering. Physiol. Rev. 98, 20972131. doi: 10.1152/physrev.00056.2017

Phua, S. C., Chiba, S., Suzuki, M., Su, E., Roberson, E. C., Pusapati, G. V., et al. (2017). Dynamic Remodeling of Membrane Composition Drives Cell Cycle through Primary Cilia Excision. Cell 168, 264-279.e15.

Pian, P., Bucchi, A., Robinson, R. B., and Siegelbaum, S. A. (2006). Regulation of gating and rundown of HCN hyperpolarization-activated channels by exogenous and endogenous $\mathrm{PIP}_{2}$. J. Gen. Physiol. 128, 593-604. doi: 10.1085/ jgp.200609648

Rohacs, T., Lopes, C. M., Michailidis, I., and Logothetis, D. E. (2005). PI(4,5)P2 regulates the activation and desensitization of TRPM8 channels through the TRP domain. Nat. Neurosci. 8, 626-634. doi: 10.1038/nn1451

Suh, B. C., and Hille, B. (2005). Regulation of ion channels by phosphatidylinositol 4,5-bisphosphate. Curr. Opin. Neurobiol. 15, 370-378.

Suh, B. C., and Hille, B. (2008). $\mathrm{PIP}_{2}$ is a necessary cofactor for ion channel function: how and why? Annu. Rev. Biophys. 37, 175-195. doi: 10.1146/annurev. biophys.37.032807.125859

Sun, J., and Mackinnon, R. (2017). Cryo-EM Structure of a KCNQ1/CaM Complex Reveals Insights into Congenital Long QT Syndrome. Cell 169, 1042-1050.e9. doi: 10.1016/j.cell.2017.05.019

Sun, J., and Mackinnon, R. (2020). Structural Basis of Human KCNQ1 Modulation and Gating. Cell 180, 340-347.e9. doi: 10.1016/j.cell.2019.12.003

Tang, Q. Y., Zhang, Z., Meng, X. Y., Cui, M., and Logothetis, D. E. (2014). Structural determinants of phosphatidylinositol 4,5-bisphosphate (PIP2) regulation of BK channel activity through the RCK1 Ca2+ coordination site. J. Biol. Chem. 289, 18860-18872. doi: 10.1074/jbc.M113.538033

Tang, Q. Y., Zhang, Z., Xia, J., Ren, D., and Logothetis, D. E. (2010). Phosphatidylinositol 4,5-bisphosphate activates Slo3 currents and its hydrolysis underlies the epidermal growth factor-induced current inhibition. J. Biol. Chem. 285, 19259-19266. doi: 10.1074/jbc.M109.100156
Ufret-Vincenty, C. A., Klein, R. M., Hua, L., Angueyra, J., and Gordon, S. E. (2011). Localization of the PIP2 sensor of TRPV1 ion channels. J. Biol. Chem. 286, 9688-9698. doi: 10.1074/jbc.M110.192526

Van Den Bogaart, G., Meyenberg, K., Risselada, H. J., Amin, H., Willig, K. I., Hubrich, B. E., et al. (2011). Membrane protein sequestering by ionic protein-lipid interactions. Nature 479, 552-555. doi: 10.1038/nature1 0545

Velisetty, P., Borbiro, I., Kasimova, M. A., Liu, L., Badheka, D., Carnevale, V., et al. (2016). A molecular determinant of phosphoinositide affinity in mammalian TRPV channels. Sci. Rep. 6:27652. doi: 10.1038/srep27652

Ye, W., Han, T. W., Nassar, L. M., Zubia, M., Jan, Y. N., and Jan, L. Y. (2018). Phosphatidylinositol-(4,5)-bisphosphate regulates calcium gating of smallconductance cation channel TMEM16F. Proc. Natl. Acad. Sci. U.S.A. 115, E1667-E1674. doi: 10.1073/pnas.1718728115

Zaydman, M. A., and Cui, J. (2014). PIP2 regulation of KCNQ channels: biophysical and molecular mechanisms for lipid modulation of voltagedependent gating. Front. Physiol. 5:195. doi: 10.3389/fphys.2014.00195

Zhang, H., Craciun, L. C., Mirshahi, T., Rohacs, T., Lopes, C. M., Jin, T., et al. (2003). PIP 2 activates KCNQ channels, and its hydrolysis underlies receptormediated inhibition of M currents. Neuron 37, 963-975. doi: 10.1016/s08966273(03)00125-9

Zhang, M., Meng, X. Y., Zhang, J. F., Cui, M., and Logothetis, D. E. (2015). Molecular overlap in the regulation of SK channels by small molecules and phosphoinositides. Sci. Adv. 1:e1500008. doi: 10.1126/sciadv.1500008

Zhao, Q., Yang, M., Ting, A. T., and Logothetis, D. E. (2007). $\mathrm{PIP}_{2}$ regulates the ionic current of $\mathrm{P} 2 \mathrm{X}$ receptors and $\mathrm{P} 2 \mathrm{X}_{7}$ receptor-mediated cell death. Channels (Austin) 1, 46-55.

Zheng, Y., Liu, H., Chen, Y., Dong, S., Wang, F., Wang, S., et al. (2021). Structural insights into the lipid and ligand regulation of a human neuronal KCNQ channel. Neuron S0896-6273, 844-848. doi: 10.1016/j.neuron.2021.1 0.029

Conflict of Interest: The authors declare that the research was conducted in the absence of any commercial or financial relationships that could be construed as a potential conflict of interest.

Publisher's Note: All claims expressed in this article are solely those of the authors and do not necessarily represent those of their affiliated organizations, or those of the publisher, the editors and the reviewers. Any product that may be evaluated in this article, or claim that may be made by its manufacturer, is not guaranteed or endorsed by the publisher.

Copyright (C) 2022 Kawai and Okamura. This is an open-access article distributed under the terms of the Creative Commons Attribution License (CC BY). The use, distribution or reproduction in other forums is permitted, provided the original author(s) and the copyright owner(s) are credited and that the original publication in this journal is cited, in accordance with accepted academic practice. No use, distribution or reproduction is permitted which does not comply with these terms. 